Historic, Archive Document

Do not assume content reflects current scientific knowledge, policies, or practices. 
United States

Department of Agriculture

Soil

Conservation

Service

Program Aid

Number 1363

\section{Going Wild With Soil and Water Conservation}
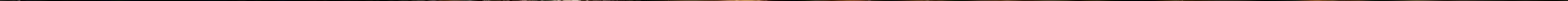


\section{Going Wild}

March 1985

Slightly revised February 1988

\section{With Soil and Water Conservation}

Your farm or ranch is a living community of plants, domestic animals - and wildlife. All are supported by the soil and water resources on your land. With good planning, you can protect the soil and water and the habitat on which wildlife depend for survival.

This booklet describes many soil and water conservation practices that can benefit wildlife. A single practice can often help, but the best approach is a conservation system-a combination of practices that fit your objectives for land use, conserve soil and water, and meet the needs of wildlife. 


\section{What Do Wildlife Need?}

\section{... Food}

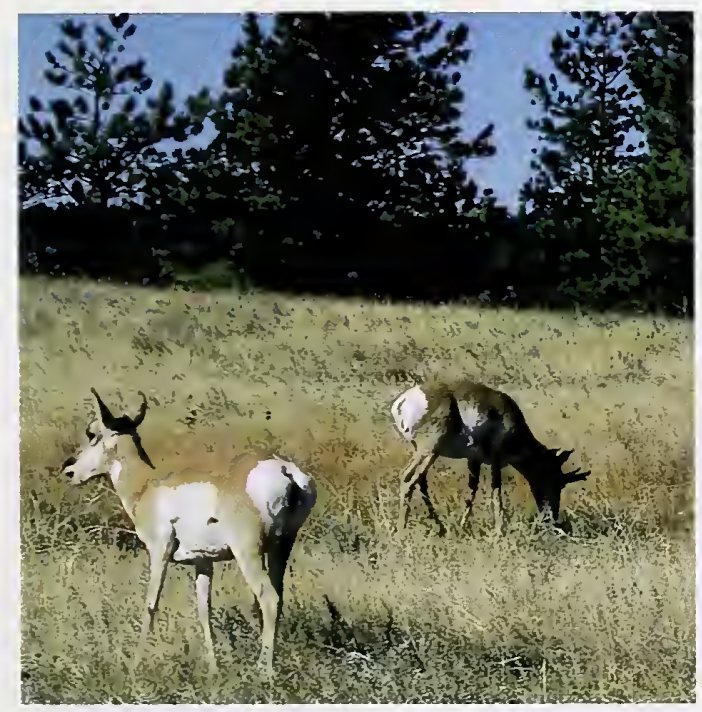

No two kinds of wildlife have the same specific habitat needs, but all need food, cover, and water. To thrive, wildlife need plentiful foods that are available all year and near good cover. Cover provides places for wildlife to nest, rest, and find shelter from natural enemies and harsh weather.

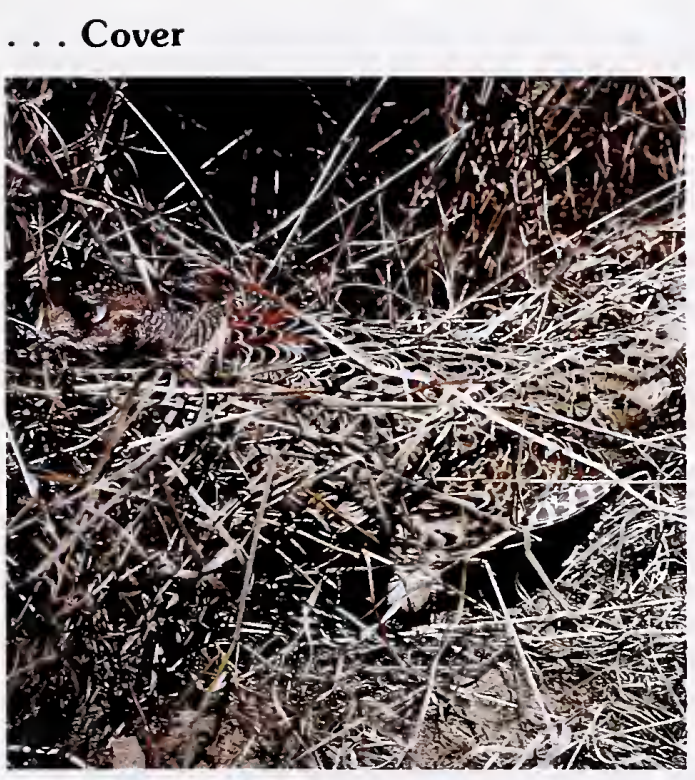

The best habitat is a diverse natural community of many plant and animal species. In diverse habitat, the plant and animal community is productive and stable because of its members' dynamic interrelationships. But farming can reduce this diversity, and less diversity means fewer wildlife.
.... Water

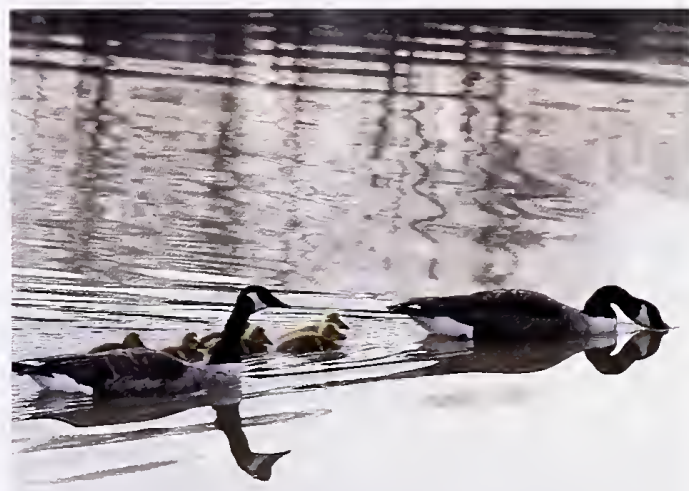

While we could no sooner abandon farming than stop breathing, our farming practices can be designed to support wildlife as well as crops and livestock . . and these practices can conserve habitat as well as soil. 


\section{How Does Farming Affect Wildlife?}

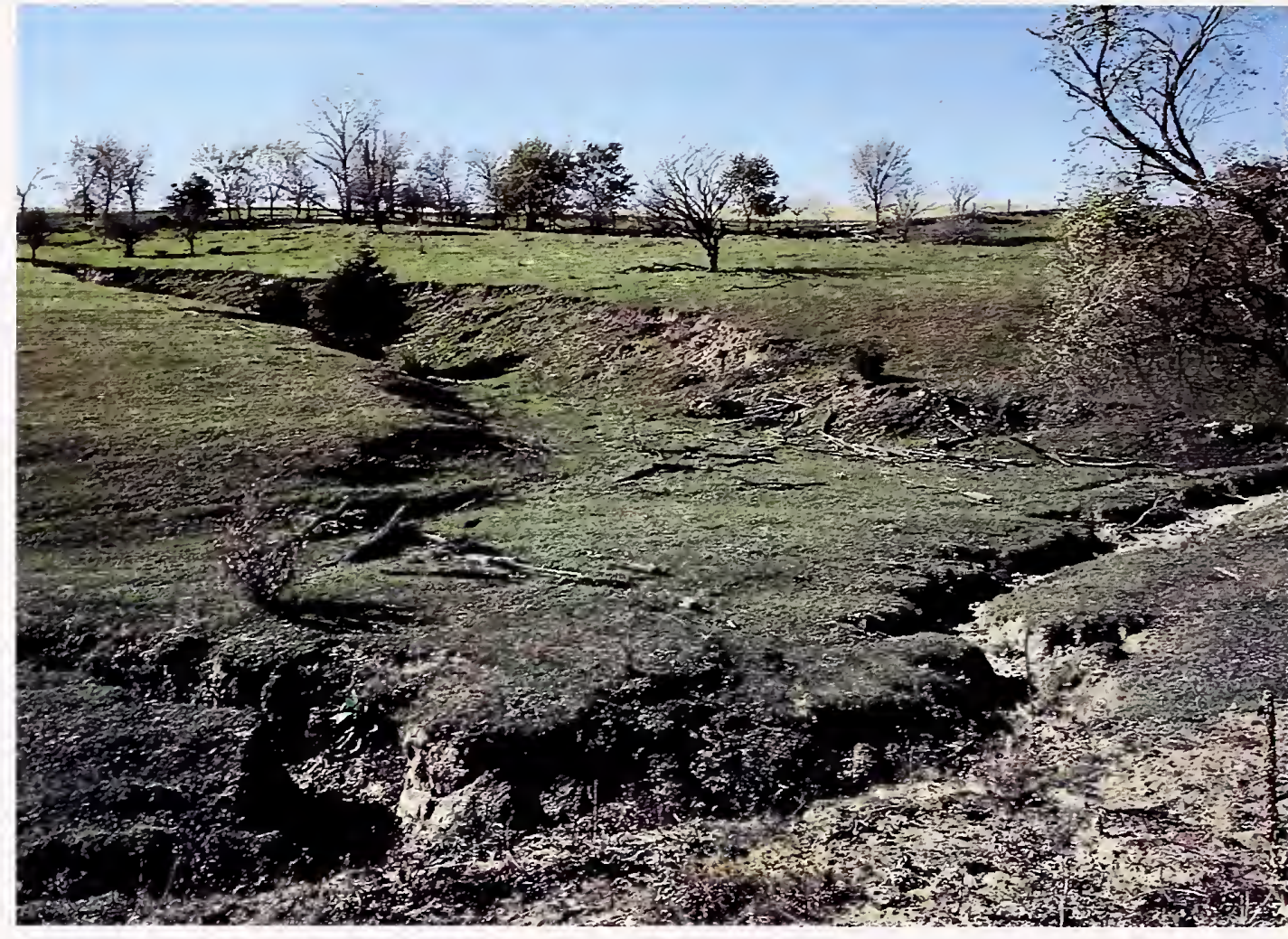

Overgrazing means fewer wildlife and less
Farming affects wildlife habitat in many ways. Mainly, farming changes the plant cover. The height, variety, and mix of plant species change when you plow, plant, cultivate, and harvest a crop . . . when you stock a range with sheep, goats. or cattle ... when you grow and cut timber. These changes can improve habitat, but when the changes are for the worse, wildlife must adjust or move on in their struggle to survive.

Over time, many management activities and methods can damage the value of soil and water resources as wildlife habitat.

For example, monoculture farming means growing the same crop on a large acreage in the same field year after year. It sharply reduces the diversity of plant cover. It may eliminate winter cover, nesting areas, and food plants.

Fall plowing bunies waste grain and other residues that can provide food or cover to help wildlife survive the winter. In many areas where farmers have drained 


\section{How Can the Soil Conservation Service Help?}

wetlands to grow crops, plant diversity is reduced and breeding and rearing areas for wetland wildlife are lost.

Overgrazing results in less food and cover for wildlife, which must then compete more intensely with each other and with domestic livestock for the food and cover that remain.

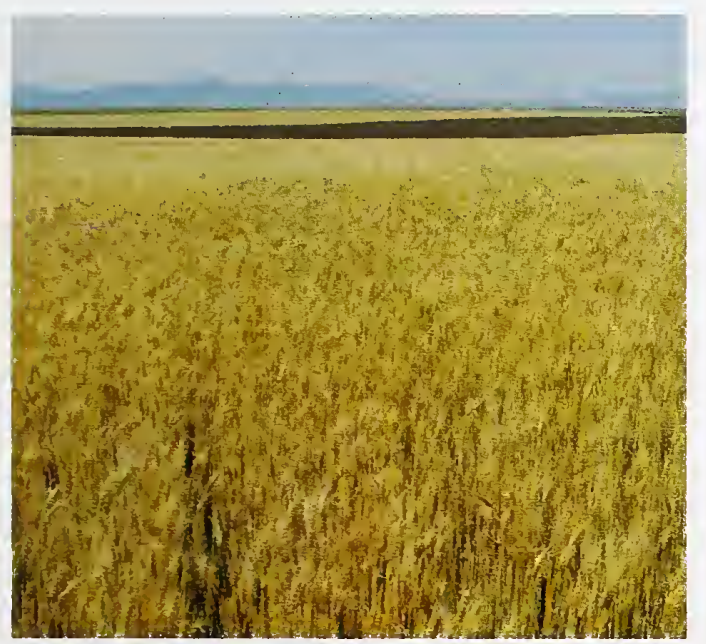

Monoculture greatly reduces the diversity of plant cover that is essential to good wildlife habitat.
The Soil Conservation Service (SCS) can help you plan a conservation system. SCS conservationists can determine the quality of wildlife habitat on a farm or ranch.

They can show you how present conditions are limiting the population of a desired wildlife species. They can explain how you can change your management practices to save soil and water and to increase or improve habitat for the desired wildlife species.

SCS conservationists can also recommend locally adapted plants to meet your wildlife and conservation goals. This booklet mentions many plants that benefit wildlife in many areas, but be sure the plants you select are adapted to the climate and soil in your area.

Conservationists use an aerial photograph as an important basis for the conservation plan. On the photo you can locate a potential site for a pond, a fence line, a terrace system, or other measure.
You can also see the mix and distribution of plant cover - such as field borders, grass waterways, brushy draws, and woodlots-or where these covers should be established. 


\section{Cropland}

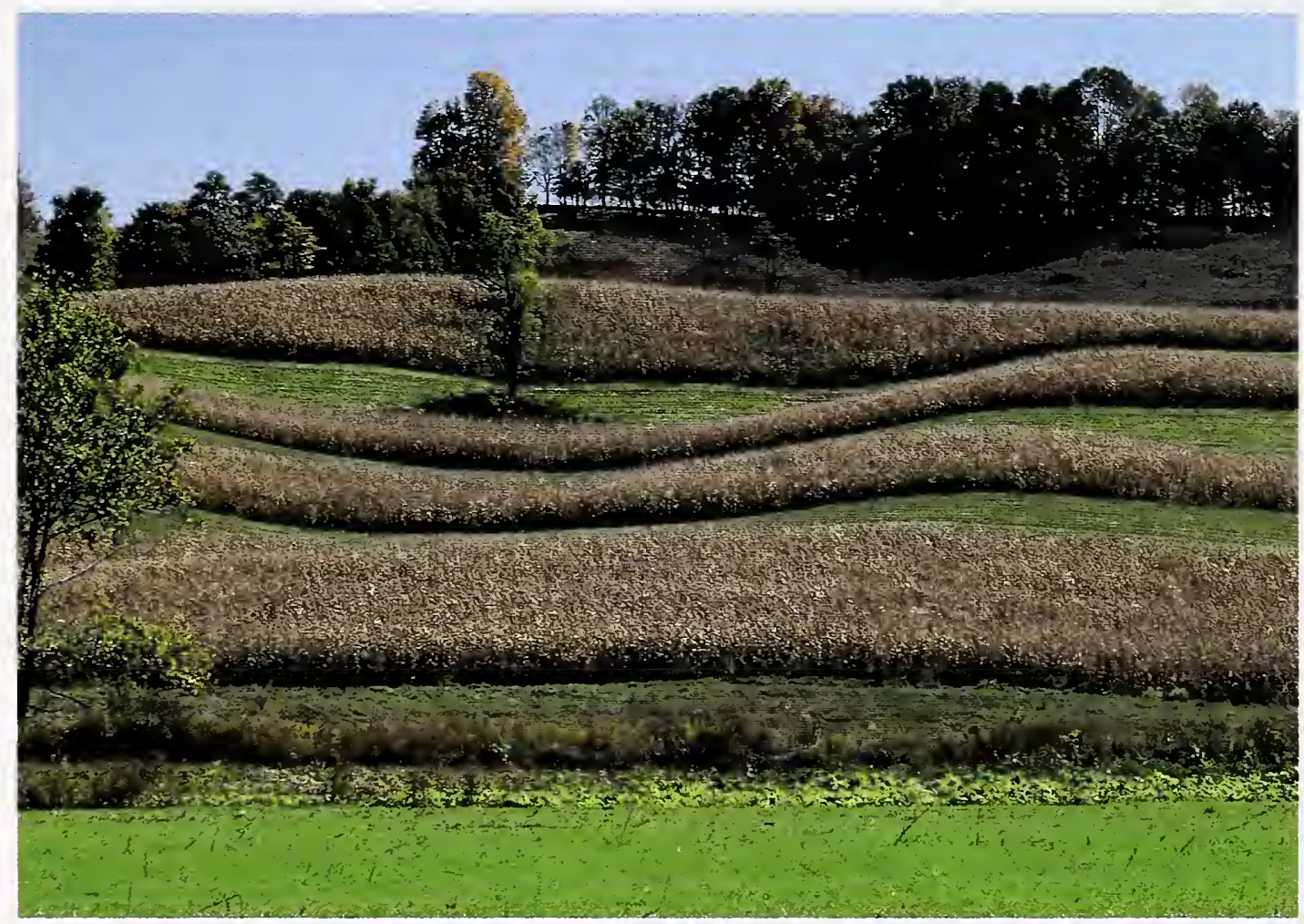

On most cropland, a combination of measures is needed to solve a conservation problem. This combination is called a resource management system, and its dual goals are good crop yield and good soil condition. To reach these goals, use the proper cultural and management practices - such as liming and fertilizingas well as the proper mix of conservation practices.

Wildlife can benefit from many cropland conservation practices, especially those for erosion control. Chief among these practices are conservation tillage, cover and green manure crops, stripcropping, grass waterways, narrowbase or bench terraces, field windbreaks. and field borders. And to supplement these practices you can manage "odd areas" that are difficult or too erodible to farm.

A well-planned resource management system produces high crop yields, conserves soil and water, and provides diverse sources of food and cover for wildlife. Beginning in the foreground, you can see a herbaceous field border stripcropping with grass and corn, scattered trees left within the field, and a steep area near the ridgetop left in natural vegetation. 


\section{Conservation tillage}

Conservation tillage refers to any of several methods of crop production that minimize cultivation and leave crop residue on the surface throughout the year.

Holding cultivation to a minimum helps maintain soil structure, reduce compaction, and prevent plowpans. Leaving crop residue on the surface reduces erosion, conserves moisture, and improves root development and soil aeration. It also increases water infiltration and improves tilth.

Conservation tillage can also help wildlife. Reducing tillage lowers the chances of destroying nests in the field. The surface residues of grasses, weeds, and waste grain such as corn or wheat provide food for many birds, deer, and small mammals. Residues of crop leaves and stalks also furnish cover for animals feeding in the field.

If the animals have residue available, they use less energy looking for food or cover. When the temperature falls below zero, the energy saved can make the difference between death and survival.

Of all methods of conservation tillage, no-till is the most effective in reducing erosion and providing wildlife food or cover. All crop residue is left on the surface. In many areas, farmers using notill can plant the crop and apply fertilizer, herbicides, and other chemicals in one trip across the field. No-till fields can support a greater number and diversity of nesting birds than clean-tilled fields.

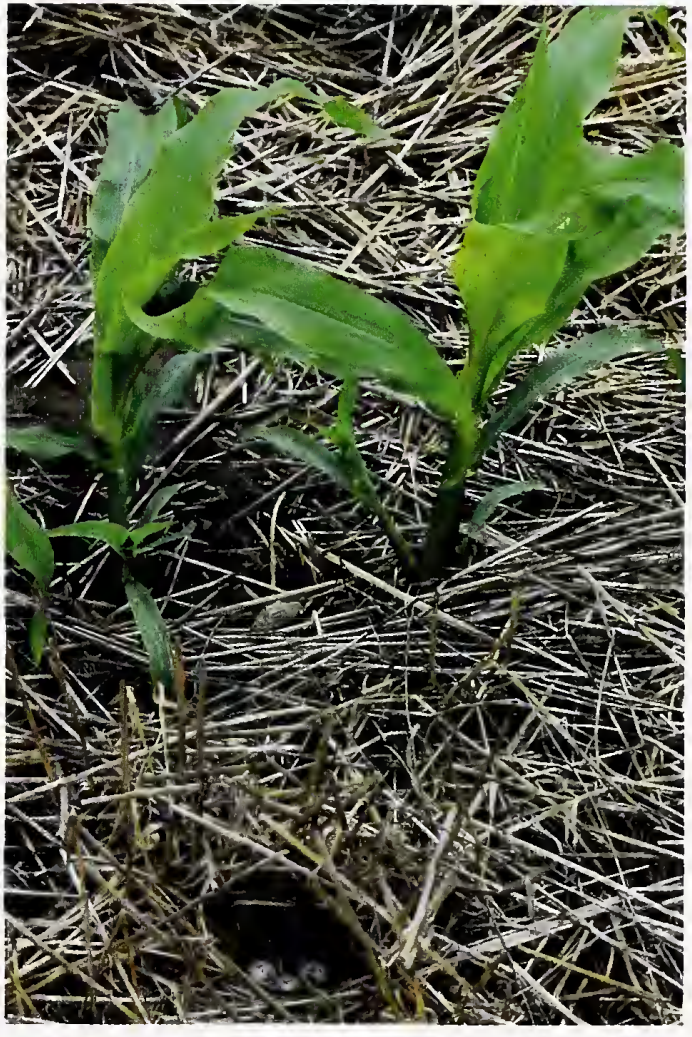

Crop residue from no-till farming conserves the soil and provides habitat for many wildlife species. 


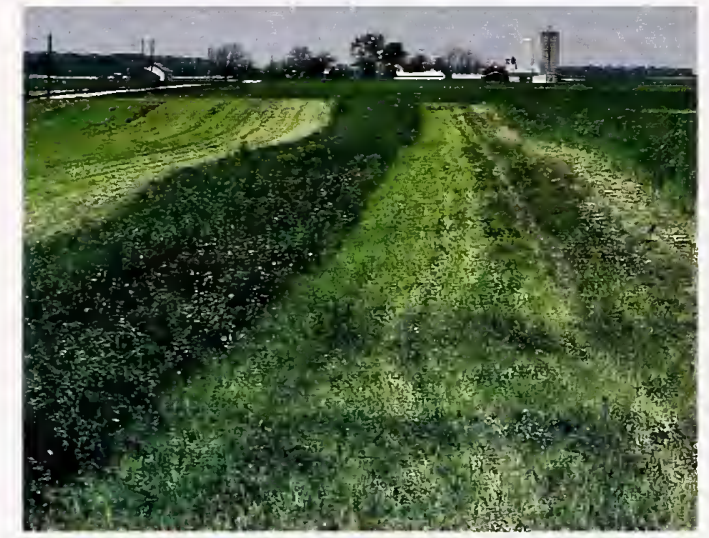

\section{Cover and green manure crops}

Grasses or legumes are used in a cropping system to reduce erosion, add organic matter to the soil, and produce forage or hay. Select a mixture of grass and legume species that will achieve these goals and benefit wildlife. For example, cereal rye and vetch provide winter forage for deer, wild turkey, and Canada and snow geese. They can also provide high-quality forage for haying or fall grazing. Delay mowing until July, after the peak of the nesting season.
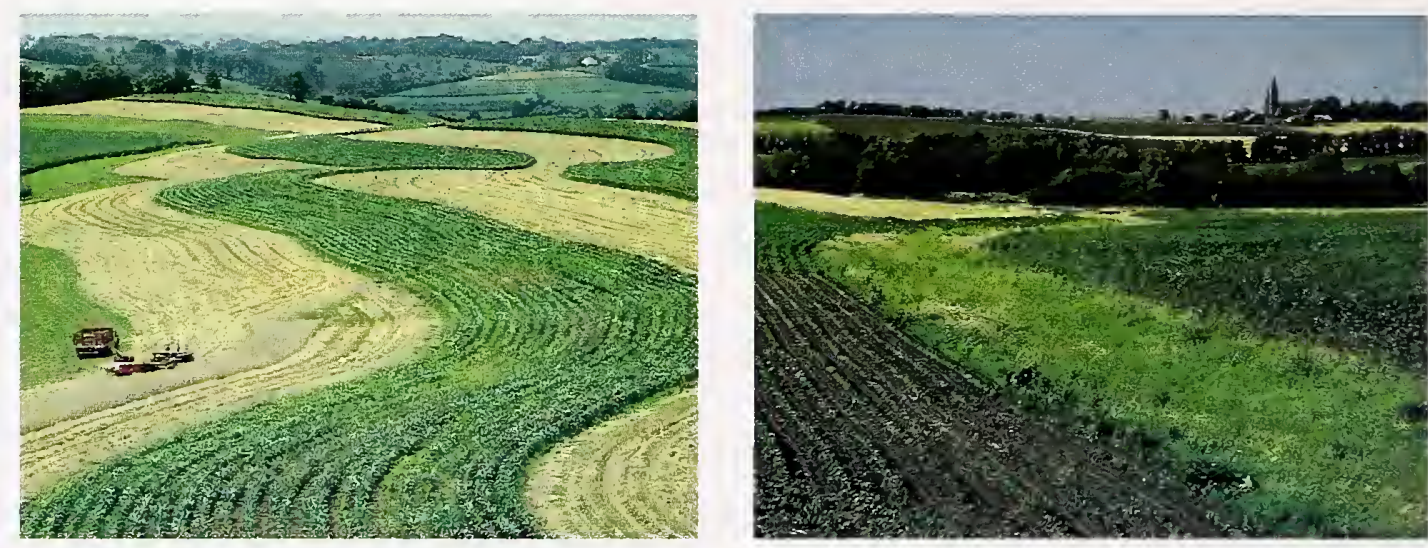

\section{Stripcropping}

In stripcropping, strips of a row crop are alternated with soil-conserving strips of small grain or a cover crop, such as grass or a grass-legume mixture. The soilconserving strips trap soil that erodes from the row-crop strips. The edges created by the alternating strips attract wildlife for feeding and nesting. Grasses and legumes in the cover strips provide food for many birds, such as pheasant.

\section{Grass waterways}

As stormwater runoff flows downhill, it tends to become concentrated and can form gullies. To prevent gullying, you may need a grass waterway to carry storm runoff slowly off the field. The waterway's depth and width are based on size of the drainage area, topography, amount and distribution of rainfall, and other factors. If you select adapted grasses and legumes that benefit wildlife, you can control erosion and provide wildife food and cover. 


\section{Terraces}

A terrace reduces erosion on sloping cropland by intercepting runoff and shortening the slope. There are several types of terraces. Their value to wildlife depends mainly on whether the terrace slopes are cropped. With narrow-base terraces, the slopes are not cropped but are planted to permanent vegetation. To benefit birds, select herbaceous species that can provide nesting and feeding areas.

SCS conservationists can help you determine which type of terrace best fits your requirements for erosion control, your cropping system, and your pocketbook. They can also help you design the terrace system.

\section{Field windbreaks}

A field windbreak is a strip of vegetation planted in or adjacent to a field to reduce wind erosion, trap blowing snow, conserve moisture, and protect crops, orchards, and livestock from wind
Nearly all field windbreaks consist of trees or shrubs or both, but there are exceptions. For example, giant reed is planted to control erosion in southwest citrus orchards; it also provides nesting cover for birds.

Select plants that are adapted to the site. To benefit wildlife, include one or more rows of shrubs, such as Manchurian crabapple, aromatic sumac, wild plum, or honeysuckle. Autumn-olive and cotoneaster are two shrubs that produce fruit eaten by brown thrasher and other songbirds, pheasant, and deer.

Russian-olive is one of many fruitbearing trees that provide wildlife food and cover. Conifers such as blue spruce and Austrian pine provide food and nesting areas for mourning dove and protective cover for quail during harsh weather.

Most plants suitable for field windbreaks are good choices for windbreaks to protect farmsteads and feedlots from frigid or torrid temperatures and drifting snow or dust.

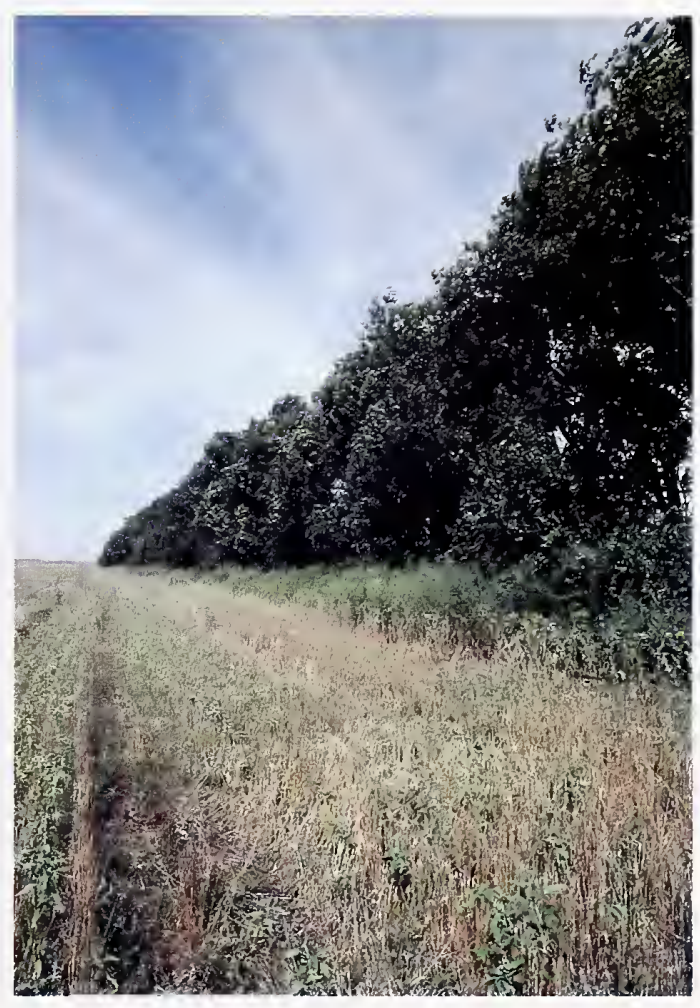

A windbreak of herbaceous species, shrubs, and trees controls wind erosion and adds diversity to habitat. 


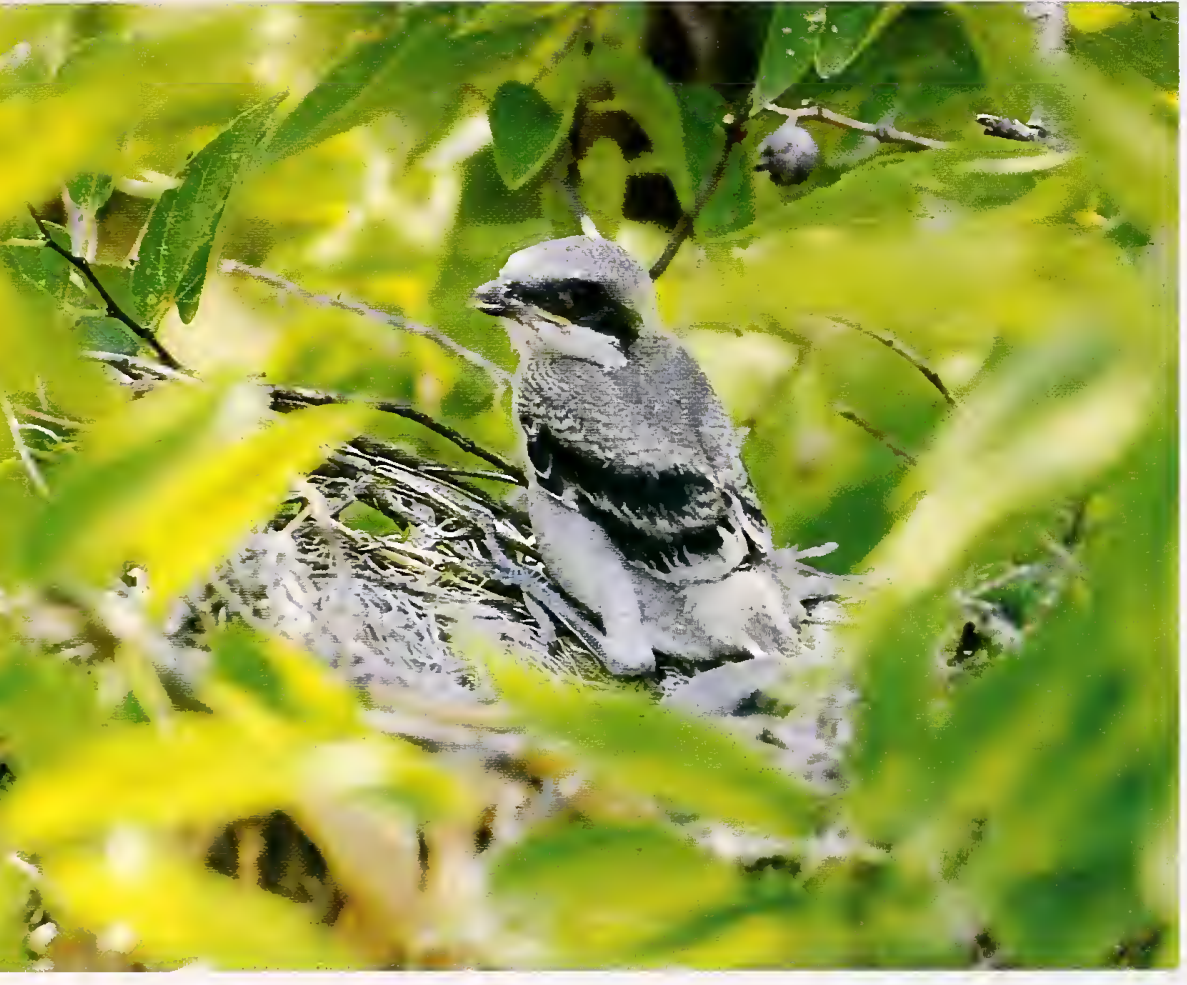

Many birds eat berries and nuts in windbreaks. Loggerhead shrike (fledgling shown in photo) are among the species that use windbreaks as nesting sites and sources of insects and small rodents.

\section{Field borders}

A field border is a strip of perennial vegetation usually established to control erosion, protect field edges used as turn rows or travel lanes for farm machinery, or reduce competition from adjacent woodland. When you plan a border, select plants

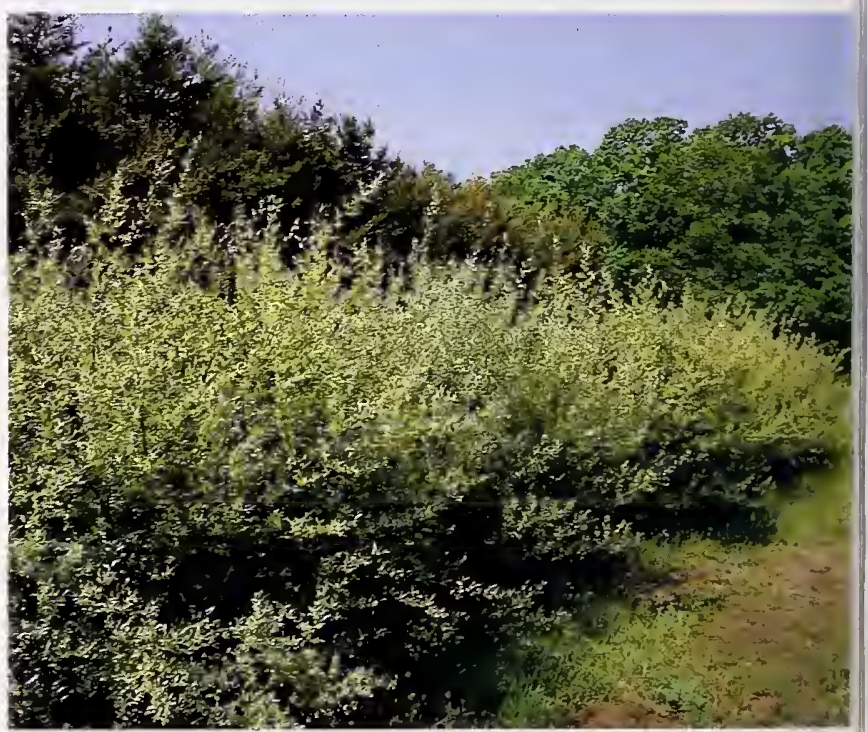

Field border of autumn-olive 
that will provide food and cover for wildlife as well as meet your management objectives for the border. You can use herbaceous plants, shrubs, or both.

Pheasant, quail, deer, and other wildlife benefit from field borders of grass-legume mixtures such as orchardgrass and ladino clover. If you select herbaceous species and want to keep woody plants from invading, you'll have to mow the borderbut mow it after the peak nesting period for ground-nesting birds such as meadowlark, pheasant, and quail. Generally, that is, don't mow until July.
Wildlife benefit from many woody species suitable for a field border. These include Russian-olive, autumn-olive, tatarian honeysuckle, Amur privet, and snowberry. Russian-olive, for example, provides food for robin and cedar waxwing and food and cover for cottontail.
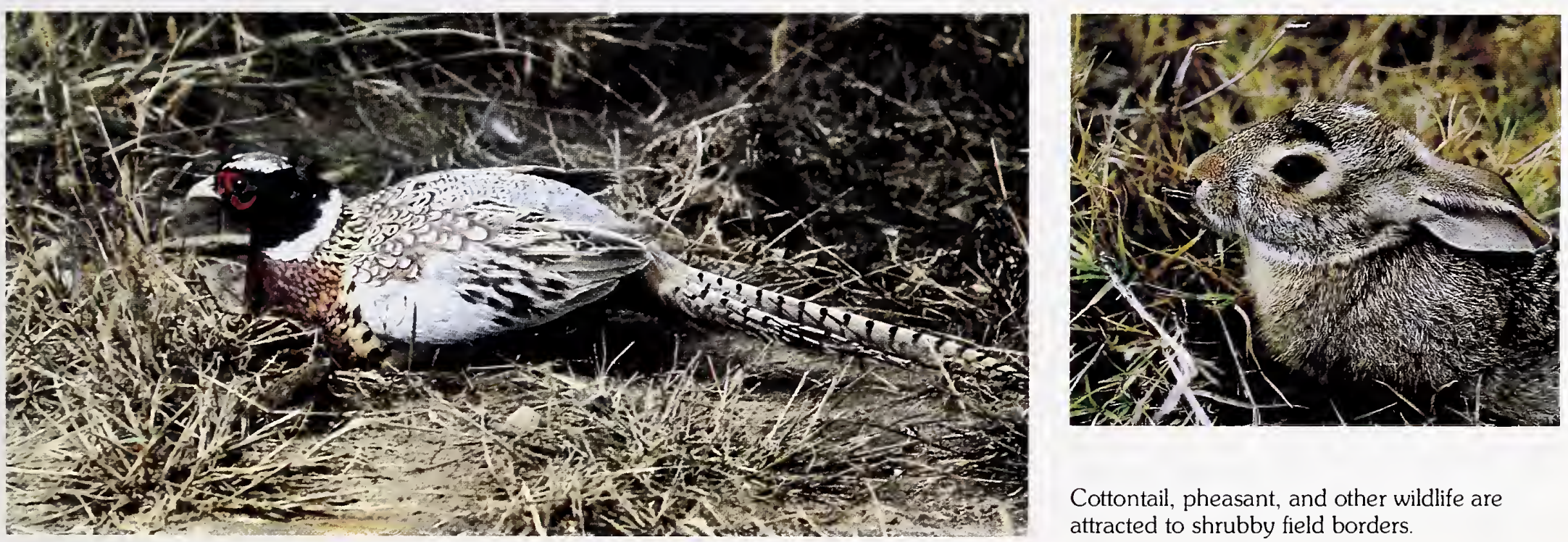

Cottontail, pheasant, and other wildlife are attracted to shrubby field borders. 


\section{"Odd areas" and critically \\ eroding areas}

Many farms have wooded areas, draws, wetlands, stony areas, rock outcrops, utility rights-of-way, highly erodible areas, or other areas that are useful primarily as wildlife habitat. These areas may be steep or wet or have other limitations that make crop production difficult. By preserving the natural vegetation or establishing food and cover plants in these areas, you supply elements of habitat that cropland does not usually provide.

On some farms, adequate erosion control requires retiring some cropland to permanent vegetation. By planting the proper combination of grasses, legumes, shrubs, and trees, you add diversity to habitat while solving a critical erosion problem.

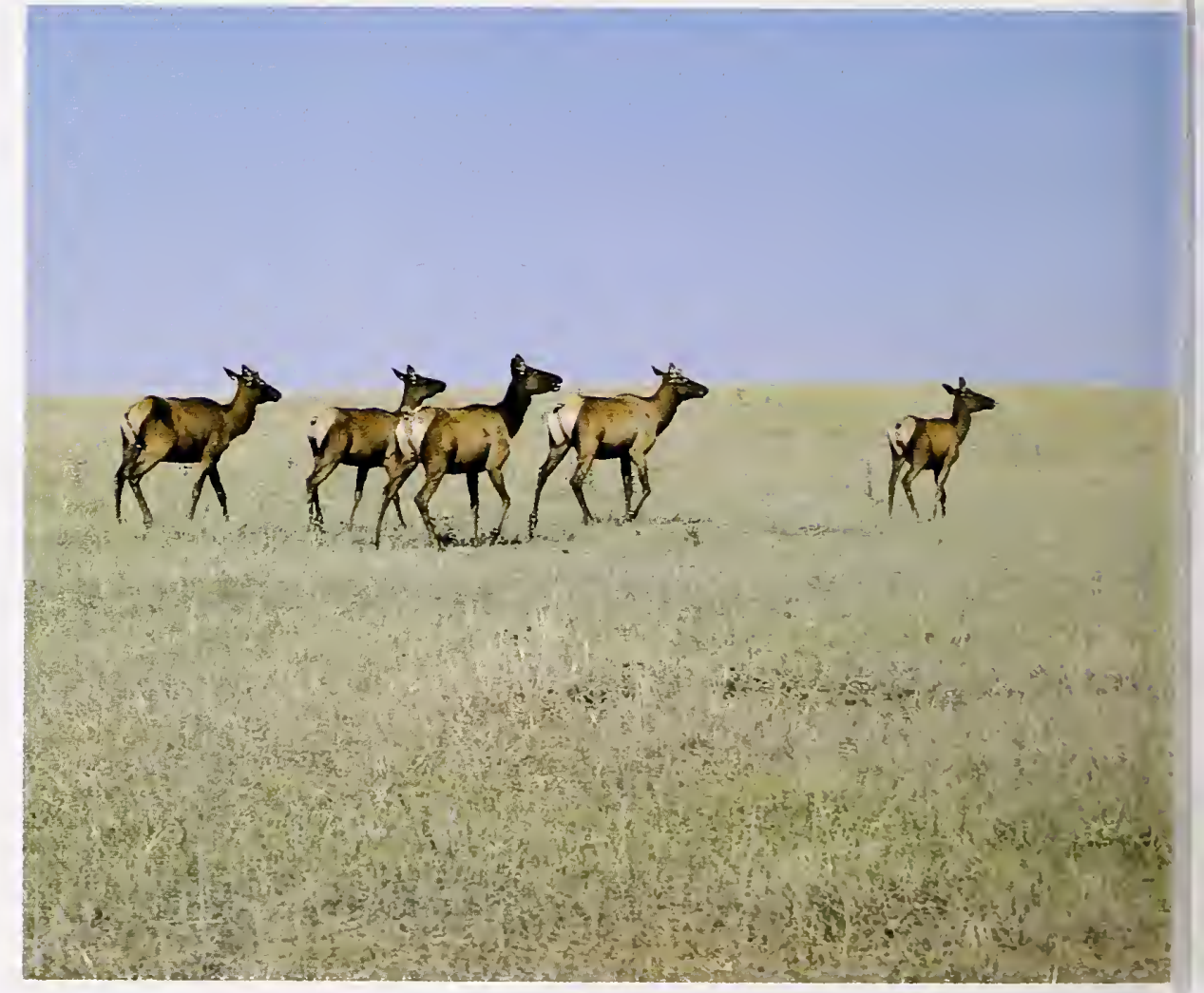

Elk on North Dakota range. With good management, most rangeland can support more livestock and wildlife. 


\section{Rangeland}

Rangeland can support both livestock and wildlife if you plan vegetation use accordingly. The quantity and quality of range vegetation depend largely on how you manage forage and cover through practices such as proper grazing, deferred grazing, range seeding, and brush management.

\section{Proper grazing}

Graze the range at an intensity that will leave enough cover both to protect the soil and to maintain or improve the quantity and quality of forage. Proper grazing helps wildlife most when it reduces forage competition with livestock, maintains a diverse plant community, and

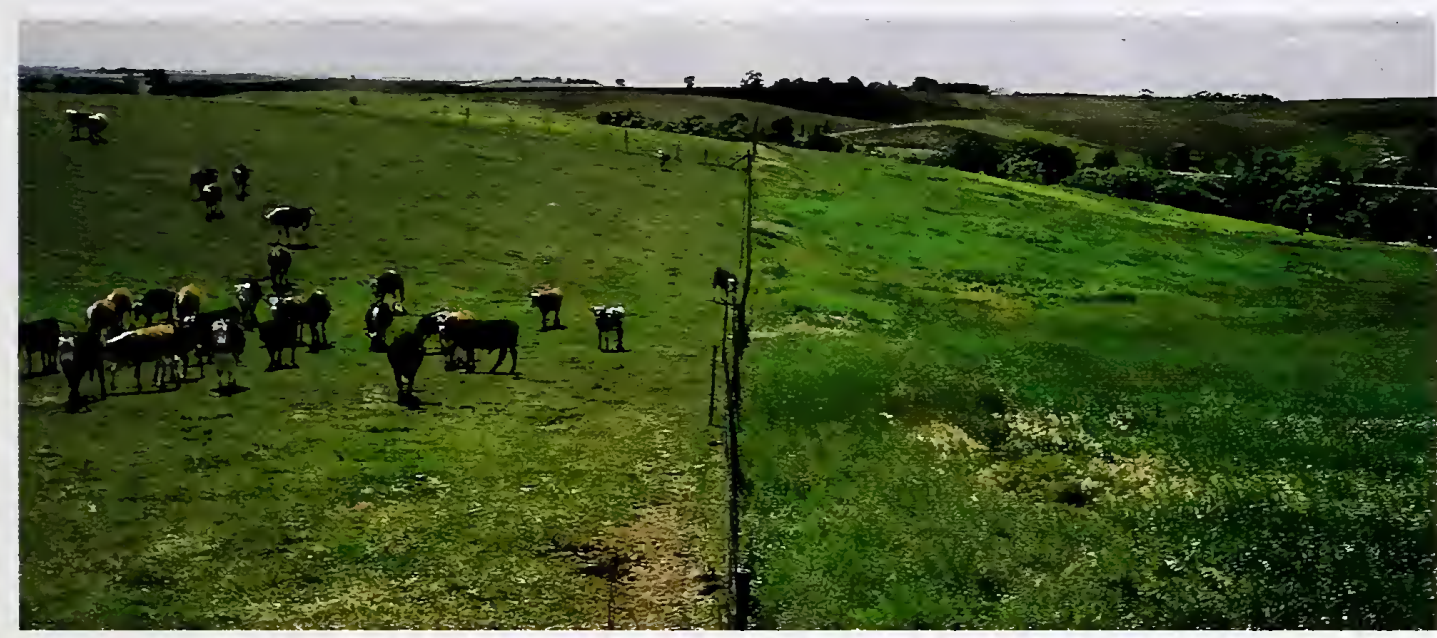

Fenceline contrast shows the effects of overgrazing and deferred grazing.

leaves herbaceous plants tall enough to provide cover for birds and small mammals.

In planning proper grazing, first determine what wildlife species you want to benefit. Then coordinate habitat needs with species of livestock, stocking density, fencing, season and length of grazing period, current range condition, and location of water supplies, salt, minerals, and feed supplements.

\section{Deferred grazing}

Grazing land should be rested periodically. If properly planned and applied, deferred grazing maintains or restores wildlife habitat by reducing forage competition between livestock and wild herbivores. The rest period can be scheduled to favor food and cover plants for desired wildlife.

Along drainageways and creeks, defer grazing during the nesting season of quail and wild turkey. On sites with cool-season grasses and forbs, defer grazing so that wildlife can use these plants in the spring. 


\section{Range seeding}

To improve poor-condition range or to convert cropland to rangeland, plant native plant species and varieties capable of providing forage for livestock and food and cover for wildlife.

Native plants are generally adapted to an area within 100 miles east and west, 150 miles north, and 300 miles south of their point of origin.

A mixture of grasses and forbs improves forage and habitat quality. Certain native shrubs are beneficial and desirable on some rangelands.

Wheatgrasses, needlegrasses, gramas, blue flax, Rocky Mountain penstemon, small burnet, bitterbrush, and saltbush are used on arid rangelands. Bluestems, indiangrass, switchgrass, Maximilian sunflower, Engelmann-daisy, chokecherry, and buffaloberry are examples of species used on semiarid and subhumid rangelands.

\section{Brush management}

When you properly plan brush control, you can maintain or improve habitat as well as provide more and better forage for livestock. First, identify the types of brushy cover that the desired wildlife species need. Second, identify the food plants-browse, mast, grasses, and forbs-that the wildlife need. Third, determine the needed amount and distribution of these cover and food plants. Use this information in planning brush control that meets your goals for range productivity.

As an example of this approach, mechanical control of mesquite in northcentral Texas has improved range condition and maintained habitat for quail. The stands of mesquite contain shrubs important to quail. The quail use hackberry, gum bumelia, and the mesquite itself for food, and they use lotebush for cover.

Quail need safe cover within about 200 feet of food sources, so ranchers using mechanical brush control often leave uncleared areas of hackberry, gum bumelia, and mesquite along drainageways. They also leave large lotebush plants no more than about 300 feet apart.

After the unwanted mesquite is cleared, forbs appear that provide food for quail. These include crotons, snowon-the-mountain, native sunflowers, and Illinois bundleflower, a native perennial legume.

If you plan to use chemicals for brush management, you can help wildlife by treating strips of brush instead of the entire area. Generally, brush management is most cost-effective when used only on the more productive soils. 


\section{Pastureland}

On most pastures only one species of grass is planted. Using a single species permits more efficient grazing and easier management, but a diverse plant cover is more beneficial to wildlife. You can take many actions on pastureland to benefit wildlife and livestock.

For greater diversity you can plant a grass-legume mixture, such as orchardgrass and red clover or common bermudagrass and crimson clover. As an alternative you can plant different grass species in adjacent or nearby pastures; for example, switchgrass, lovegrass, and kleingrass. In cool climates, include some warm-season grass pastures, using species such as switchgrass, big bluestem, or indiangrass.

If you select adapted plant species with care, you can increase the length of the grazing season, improve forage quality, and provide more food and cover for wildlife.

Wildlife can also benefit from improved management of pasture. Maintain fertility. for example, to promote plant vigor and

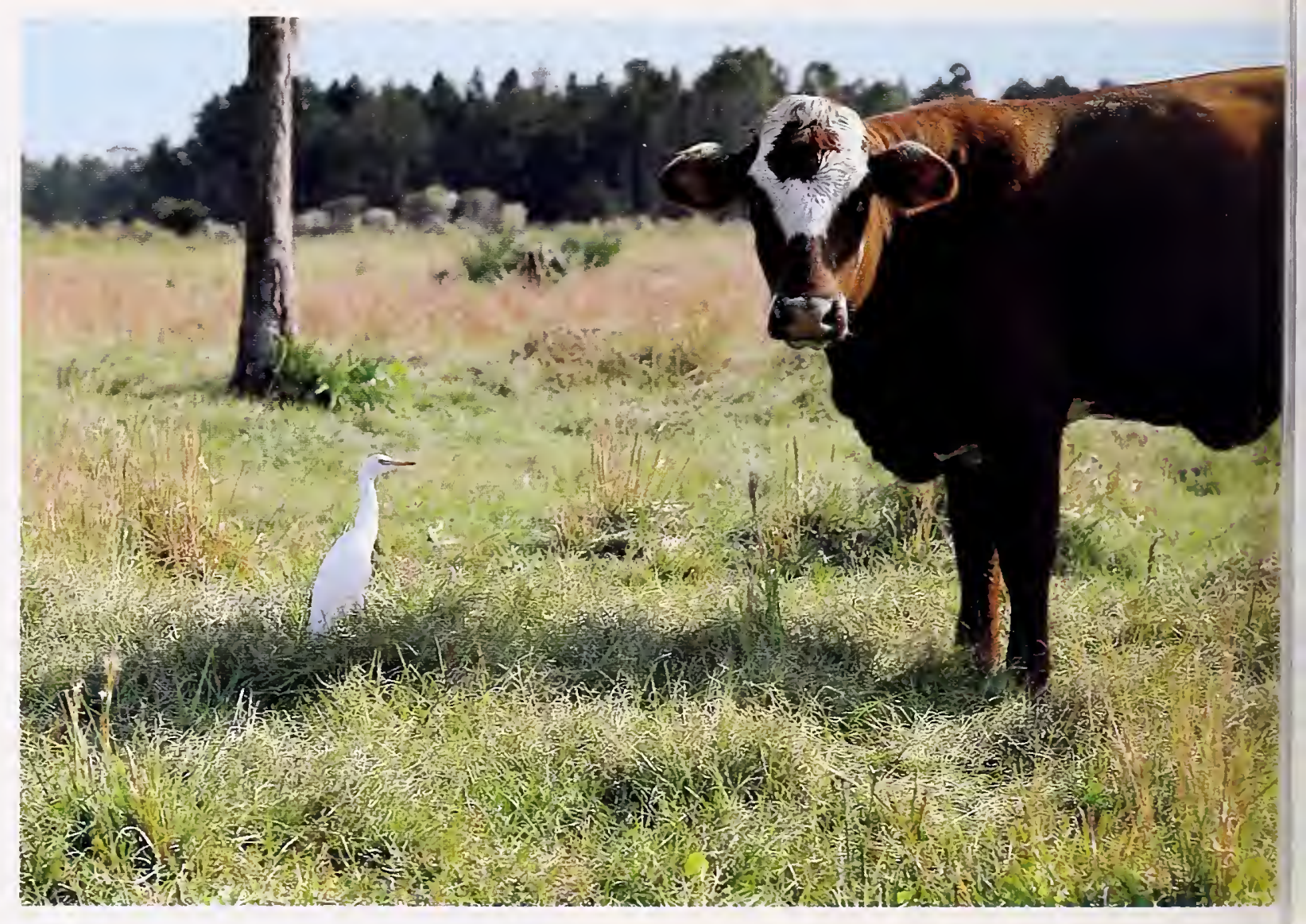

Cattle egret and friend share a Florida pasture. 


\section{Woodland}

increase production: this helps both livestock and wildlife.

Livestock operators generally try to postpone the seed set of forage plants, but you can let some small areas go to seed for use by wildlife. With proper grazing you can maintain adequate cover for ground-nesting birds.

If you mow for weed control, postpone it until after the nesting season has peaked or leave some small areas unmowed. In brush management you can help wildlife by leaving shrub cover along fences and drainageways and in odd areas.

Where pasture is adjacent to woodland, deer and many other species will increase their use of the pasture if its woodland border is irregular instead of straight.

Selective harvesting -in this instance, every seventh row-causes less disturbance to the soil-protecting leaf litter and to woodland inhabitants.
In managing land for wood production, you can incorporate practices that provide wildlife food or cover.

By selecting the proper plant species, you can improve wildlife habitat while you control erosion on access roads, fire roads, firebreaks, and other areas.
For example, you can plant these sites with birdsfoot trefoil and tall fescue where adapted. These plants can control erosion while providing forage for deer and a source of seed and insects for wild turkey. Other plants that benefit wildlife and control erosion in these sites are partridge

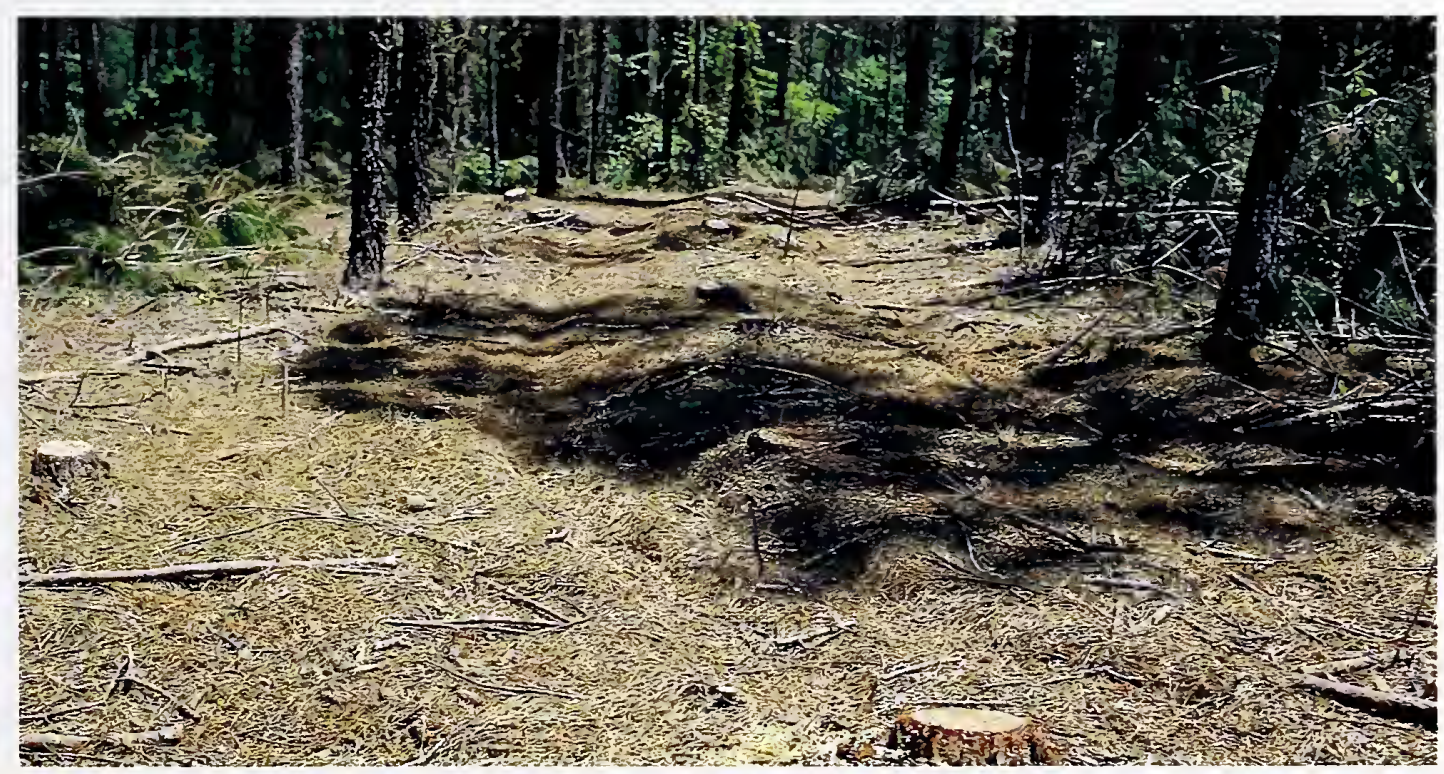


pea, wild reseeding soybeans, reseeding cowpeas, switchgrass, bahiagrass, sericea lespedeza, and shrub lespedeza.

Fescues and clovers are desirable for firebreaks. Where they stay green all year, they do not carry a fire readily. They control erosion well. Many wildlife species eat these plants and the insects they harbor.

Selective harvesting disrupts the woodland environment less than clearcutting; as a result, selective harvesting has less adverse effect on wildlife habitat. If clearcutting is to be used, however, make the clearcuts in long, narrow rectangles with undulating margins instead of large, round or square cuts.

By interspersing different-age forest stands, you can improve habitat as well as maintain timber production. You can intersperse stands by harvesting them in parcels of about 50 acres or less. This technique creates plant communities more diverse than those in unmanaged or evenaged forest. Deer, wild turkey, grouse, and quail are some of the species that benefit from small-parcel harvesting.

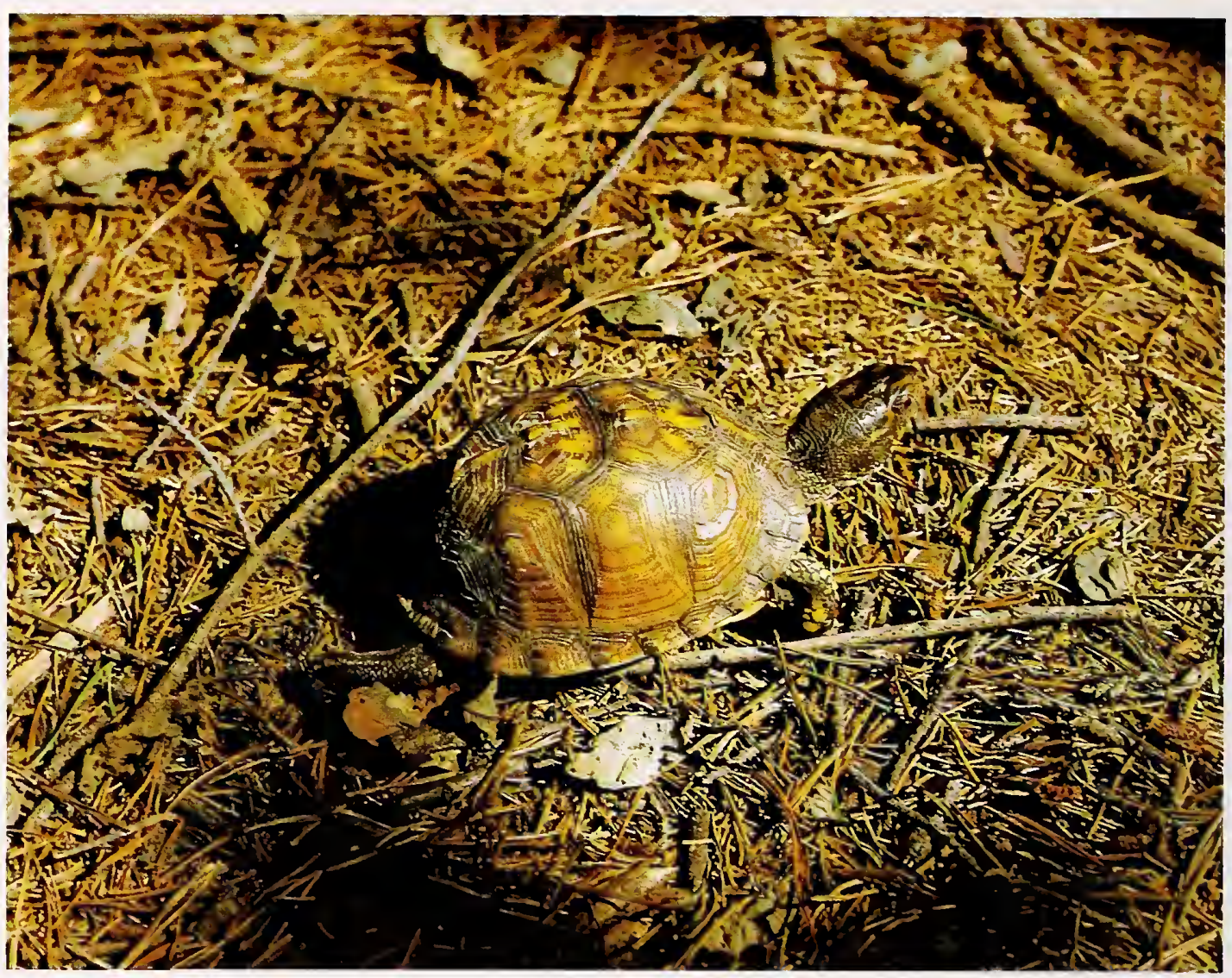

Box turtle. 


\section{Ponds}

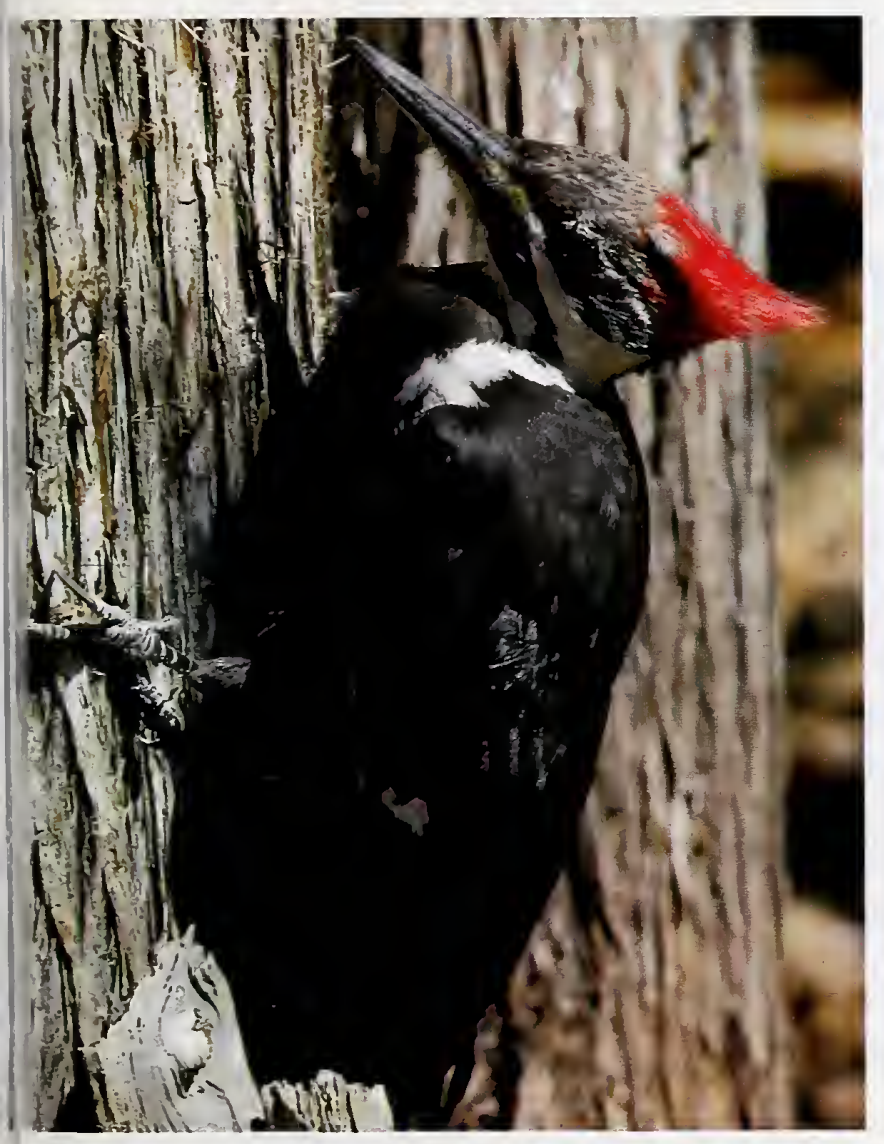

Pileated woodpecker.
When converting mixed woodland to pine, leave hardwoods along drainageways and creeks and in small upland groves. In pine monoculture, prescribed burning can benefit wildlife in many ways, mainly through stimulating the growth of native grasses and legumes.

In harvesting or improving a timber stand, leave enough mature dead or decadent trees to provide homes for mammals and birds that live in tree hollows.
An earthen pond has many uses on a farm or ranch. It can serve as a structure to control gully erosion or as part of a livestock watering system. If large enough, a pond can supply irrigation water. A pond can also provide food, cover, and water for wildlife.

If you build a pond in the right place and properly construct and manage it, it can last many years. To protect water quality you have to manage not only the pond itself, but also the watershed that drains into it.

Well-managed ponds as small as onequarter acre can receive heavy use by wildlife. The best ponds for wildlife are fenced to keep out livestock, adjacent to herbaceous and shrub cover, and near dense, woody cover. Fencing out livestock prevents them from damaging the spillway and embankment and from muddying the water. To provide water for livestock, you can pipe the pond water to a trough.

If you leave a protected 50-foot-wide grass filter strip around the pond, you can help maintain water quality and provide 
nesting sites for waterfowl. Building an island in the pond also provides nesting sites.

Before you install a pond on grazing land, determine livestock needs for water and the distance they will have to travel for it. Then consider the needs of wildlife. On rangeland, you'll generally need a pond or other water supply available for every 640 acres. Cattle require 15 gallons of water per day, so plan for enough for them and add extra for wildlife. In water tanks or troughs, you can install devices that make the water available to birds.

Where a pond is not desirable or feasible, you may be able to develop a spring to supply water for livestock and wildlife.

If you plan a pond for fish production, you'll need to consider factors such as water permanence, temperature, depth, and turbidity.

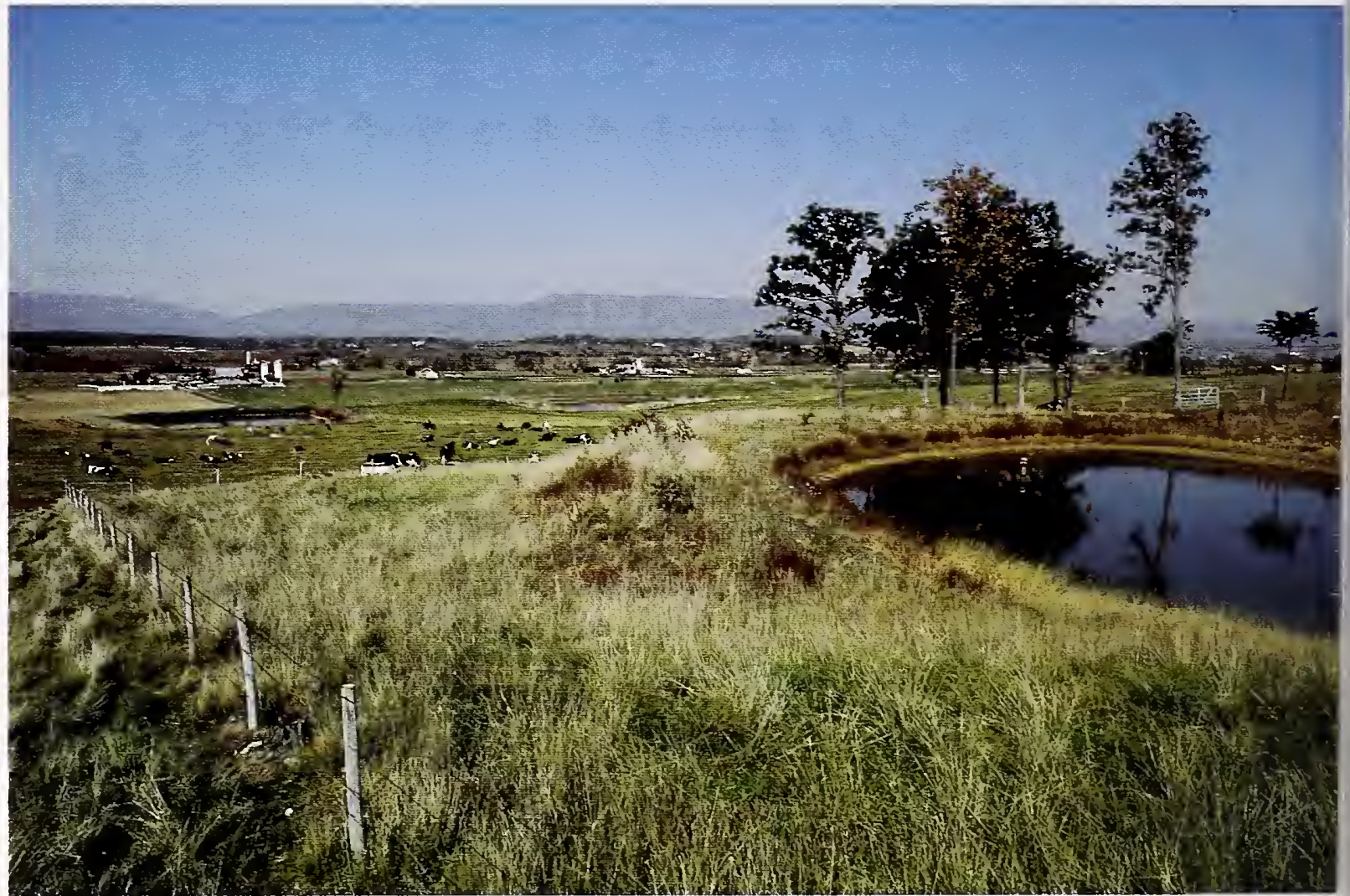

This pond, built to furnish water for livestock, is fenced to protect the pond embankment and maintain water quality. Fencing also protects the dense vegetation for use by wildlife. 


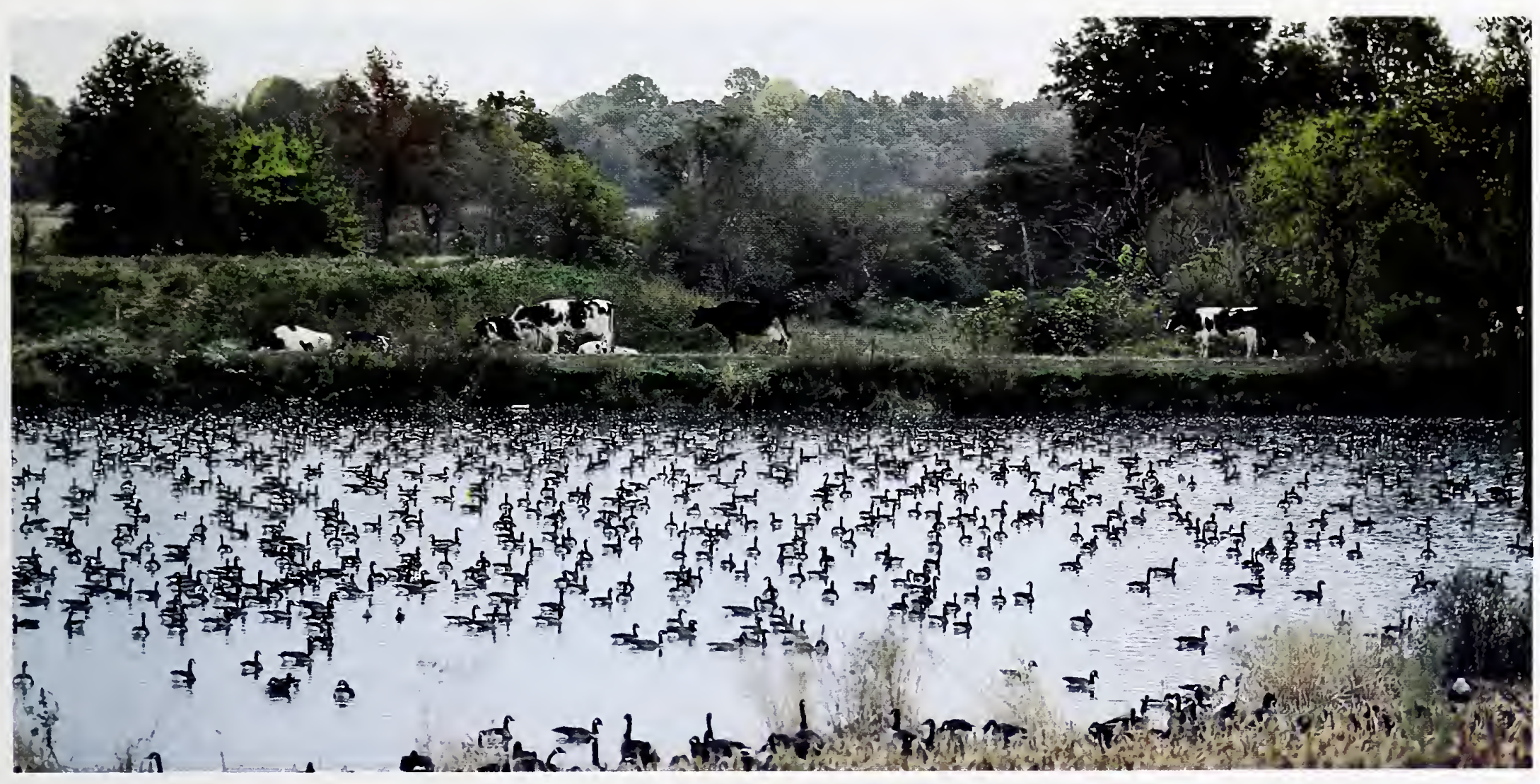

Farm ponds are important feeding and resting areas for migratory waterfowl. 


\section{Pesticides}

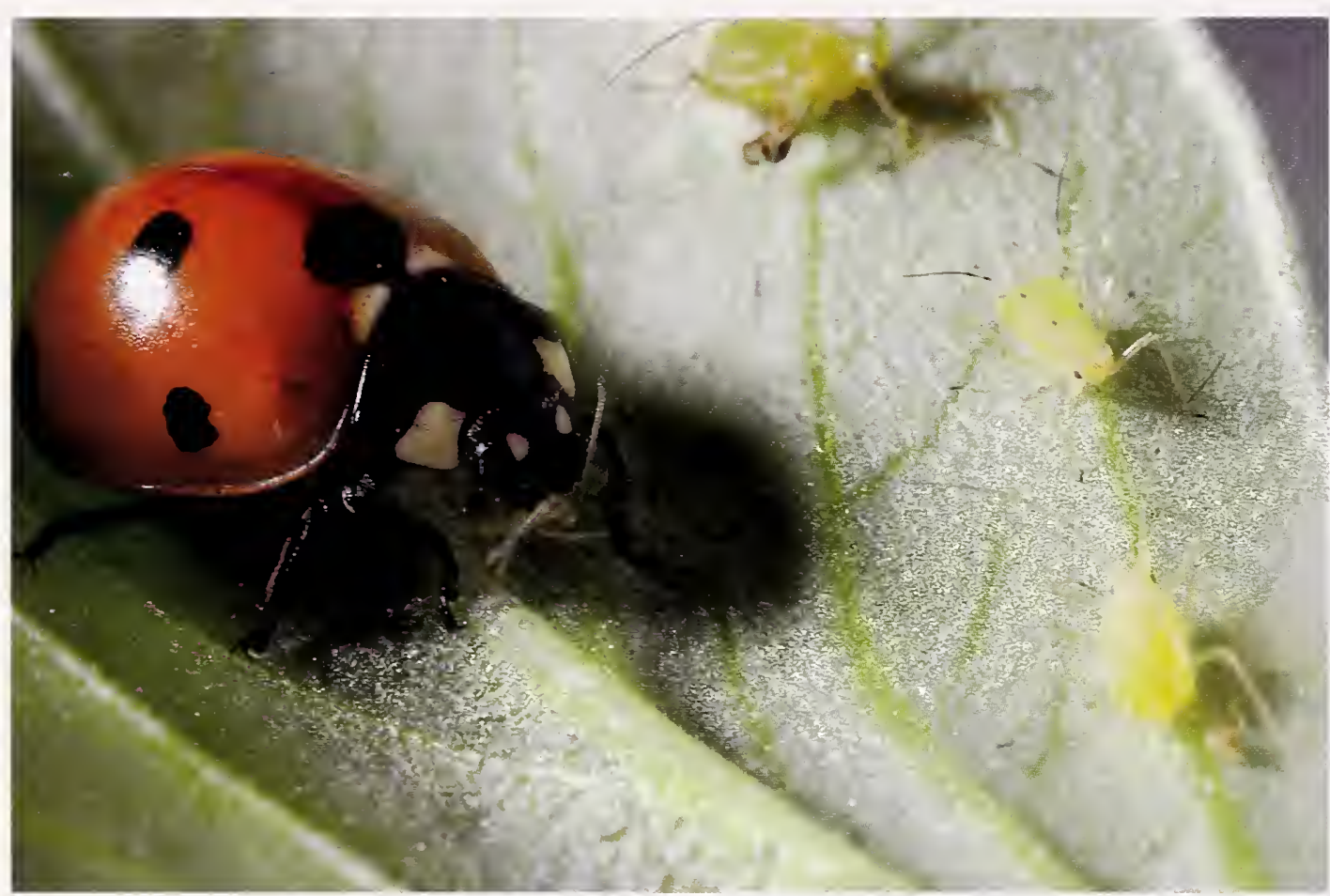

A seven-spotted ladybird beetle gobbles the first of its four dinner entrees of pea aphids. As farmers increase the use of natural predators and other forms of integrated pest management. they can reduce the application of potentially harmful pesticides.
Be careful with pesticides. If improperly used, they can harm fish and wildlife, beneficial insects. domestic animals, crops, other desirable plants, water resources-and people.

Use a pesticide only if you know it's needed, and be sure its use is registered with the appropriate Federal or State agencies. In use, application, and disposal of a pesticide, follow the directions on the label.

To reduce the use of chemical pesticides, many farmers apply integrated pest management, which is a combination of techniques. It can include the use of natural predators, biological controls, and pest-resistant crop varieties. It can also include making changes in field conditions. For example, rotating the crops can reduce or prevent a long-term buildup of certain pests.

Farmers who use integrated pest management closely monitor pest levels in their fields. They use chemical pesticides only when necessary. In this way they can reduce the potential for harmful effects of 


\section{For More Information}

pesticides, including effects on beneficial insects such as bees and effects on fish and wildlife.

Research on techniques of integrated pest management is conducted by the Department of Agriculture's Forest Service and Agricultural Research Service in cooperation with universities and other institutions.
For further information and help on how to improve wildlife habitat while you conserve soil and water resources, contact the local office of the Soil Conservation Service or your local conservation district. SCS is generally listed in municipal telephone directories under "U.S.

Government, Department of Agriculture." You can also get help and information from the Cooperative Extension office in your county and from your State fish and game department.

All programs and services of the U.S.

Department of Agriculture, Soil Conservation Service, are offered on a nondiscriminatory basis, without regard to race, color, national origin, religion, sex, age, marital status, or handicap. 
